\title{
Can there be alternative-FaCts? HANNAH ARENDT'S ANSWER AND ITS POLITICAL IMPLICATIONS
}

\author{
[ Pode haver fatos alternativos? A Resposta de Hannah Arendt e \\ SUAS IMPLICAÇÕES POLÍTICAS ]
}

Rafael Lembert Kasper * Universidade Federal do Rio Grande do Sul, Brasil

\begin{abstract}
: this paper addresses the current discussion on "alternative-facts" and public lying focusing on Hannah Arendt's take on the relation between truth, reality and politics. It argues that much of what is assumed as novel and unexpected in the ongoing discussion has been anticipated by Arendt in the 1950's and the 1960's. Furthermore, it states that her insights and categories provide a deeper understanding of the matter, thus contributing to dismiss common dead-locks in recent debate. Still, there are, in Arendt's analysis, perplexities - explored and unexplored by her - that deserve our attention in order to grasp the nature of facts and truth. In this line, this paper answers the question put forward in its title - Can there be alternative-facts? - relying on a (Arendt inspired) defense of objective truth, which requires a specific definition of politics and some qualified ontological claims about political reality.
\end{abstract}

KeYwORDS: Truth; facts;. Politics; opinion; Hannah Arendt
RESUMO: Este artigo aborda a discussão atual sobre mentiras públicas e "fatos alternativos" baseado na visão de Hannah Arendt sobre a relação entre verdade, realidade e política. Argumenta que muito do que é considerado novo e inesperado na discussão em curso foi antecipado por Arendt nos anos 50 e 60 . Afirma, além disso, que seus insights e categorias fornecem uma compreensão mais profunda do assunto, contribuindo assim para descartar os dead-locks comuns em debates recentes. Ainda assim, há, na análise de Arendt, perplexidades - exploradas e inexploradas por ela - que merecem nossa atenção para apreender a natureza dos fatos e da verdade. Seguindo essa linha de argumentação, este artigo responde à questão apresentada em seu título - Pode haver fatos alternativos? admitindo a possiblidade de uma defesa (inspirada em Arendt) da verdade objetiva, que requer uma definição específica de política e algumas afirmações ontológicas qualificadas sobre a realidade política.

Palavras-chave: Verdade; fatos; política; opinião; Hannah Arendt

The current widespread onslaught on factual reality has been marked by two recent events: Donald Trump's Counselor Kellyane Conway defense of the White House Press Secretary's statement about the number of people attending the Presidential inauguration (the secretary called it the "largest audience to ever witness an inauguration...") as an "alternative-fact"; and the Oxford Dictionary's definition, in 2016, of "post-truth" as the international word of the year. But the phenomenon of fake news is not as new as it might seem. In the 1960s, Hannah Arendt had already called

* Doutorado em Filosofia pelo Programa de Pós-Graduação em Filosofia da Universidade Federal do Rio Grande do Sul com periodo saduiche na Freie Universität, Berlim, Alemanha. m@ilto: rafaelkasper@gmail.com 
upon "the clash of factual truth and politics, which we witness today on such a large scale" (ARENDT, 2006, p. 231).

Arendt even emphasized a trend that a recent research by the Massachusetts Institute of Technology (MIT) claimed to be unexpected: that false news spread faster than true ones ${ }^{1}$. More than 50 years ago, Arendt reminded the freedom of the liar, who can "fashion his 'facts' to fit the profit and pleasure, or even the mere expectation, of his audience", being so "more persuasive than the truthteller" (ARENDT, 2006, p. 247). Although Arendt could not predict the technological elements added by social media and digital tools to the dynamics of public lying, she presented important definitions and insights. Her terms are useful to throw light into the impasses of the actual debate.

An analyst, for instance, after widely defining "post-truth performances" - from plain lies to buffoonery, from mere bullshit to "engineered silence" -, argued in favor of democratic subjectivism by concluding that "Democracy is not a True and Right norm" (KEANE, 2018). Even Arendtian scholars seem to be unable to get rid of the paradoxes of "postmodern" realities, where the performative character of the real may be open to the possibility of "contradictory facts" (BIRMINGHAM, 2010, p. 77). Without preaching what a historian called "cult of facts" (CARR, 1986, p. 9), but also without simply putting truth aside, Arendt worked on a more subtle, mediated perspective on the issue, one which relied on what I will call phenomenology of truth.

\section{ARENDT'S PHENOMENOLOGY OF TRUTH}

By referring to Arendt's phenomenology of truth, I want to stress the distinctions proposed by her in grasping the phenomena of truth (of searching for, establishing, verifying, and so on, truth). Truth has no single meaning. There are different ways of experiencing it. In Truth and Politics, Arendt approached the problem from a political point of view. From the perspective of the political realm, where one exists with others, Arendt discarded as a-political, or even anti-political, truths such as the mathematical truth (which relies on the self-reference of logic), scientific truth (which depends on research, tests and validations pursued in the technical isolation of the laboratory), rational truth (such as those products of speculation and value-postulation of pure reason). In broad terms, these truths are non-political for they are the result of the relation of the self with the self $(\mathrm{KOHN}, 2010$, p. 181) - and not from that "web of relationships" that, for Arendt, characterized the political (ARENDT, 1998, p. 181).

In this sense, an undifferentiated approach to truth and a homogenizing definition of fact blurs the lines which may restore a sense of objectivity for political lives. Adopting the standpoint of a plurality of selves, Arendt defined factual truths as the truths of politics. But what is a fact? She pointed to the following aspects: facts concern "events and circumstances in which many are involved" (2006, p. 233); they depend on testimony and witnesses, on being seen by the "eyes of the body, and not the eyes of the mind" (idem, ibid.); they need to be politically established and they exist "only to the extent that [they are] spoken about" (idem, p. 234); they concern particular stories which describe singular events (idem, p. 257); at some extent, they are always new and fresh, insofar as human agents, contexts and consequences are unique. In these conditions, factual truths are only "modest verities" (idem, p. 227), fragile statements about "the ever-changing affairs of men" (idem, ibid.).

They are modest, but they are politically indispensable. They stabilize the political by providing a ground of stories and experiences from which opinions, evaluations, judgments - in short, informed debate - can emerge. As an extension of her phenomenology of truth, Arendt worked on a phenomenology of political speech, according to which factual truths differed from opinions and judgments. Arendt stressed that, although facts are not opinions, facts and opinions do not contradict each other. Indeed, facts precondition opinion and political thought in general. Opinion cannot replace facts, for opinion and judgment refer to facts, stories and events registered 
within a given community. "Freedom of opinion", Arendt stated (2006, p. 234), "is a farce unless factual information is guaranteed and the facts themselves are not in dispute".

\section{PARAdoxes OF FACTUAL TRUThS}

The nature of factual truths, however, arises several perplexities. First, facts are pre-political and political. They are pre-political in the sense that "they are beyond agreement, dispute, opinion, or consent" (ARENDT, 2006, p. 235). That Germany invaded Belgium in 1914 and that L. Trotsky was a leader of the Bolshevik revolution in Russia are facts and thus not open to dispute: they do not depend on people's consent confirming their existence. Moreover, they tend to have a longer existence than powerformations and social moods. In Arendt's words, factual truths are supposed to be as permanent as are "the ground on which we stand and the sky that stretches above us" (2006, p. 259). They form a sort of immutable universe of references which men accumulate and recall under the name of history, whose stories survive even the decline of the civilizations that originated them.

Facts, however, are political in at least two senses. They refer to events initiated by political beings in political contexts. Arendt emphasized that subjective experiences of the mind or psychological sensations do not produce facts. Facts refer to public, visible, witnessable experiences "in which many are involved". In a second sense, facts become political the moment they are put in a context of debate and interpretation. Paraphrasing Georges Clemenceau: the fact that Germany did invade Belgium is not debatable in itself; but the meaning of the fact, the surrounding elements, the interpretation over its origins, its developments, the consequences of the event, its moral evaluation and its political judgment are permanently open to discussion (ARENDT, 2006, p. 234).

The fact becomes debatable (hence, political) as soon as citizens start to make sense of it, judging it, blaming or praising it, amplifying its meaning from the what happened to the why and how it happened, to the should it have happened?, and to the plural perspectives through which these questions may be addressed. Since "facts have no conclusive reason whatever for being what they are" (idem, p. 238), this evaluative debate is never-ending. This, indeed, has to do with "the price of freedom" - not only the freedom of speech, but the ontological freedom of human acts, which, resulting from contingency and not from necessity, always "might have been otherwise" (idem, ibid.). No one debates whether the sun should come out tomorrow. It will anyhow. But citizens debate the stories of heroes and leaders, of social groups and nations, the stories of invasions and revolutions, for they are examples of how to act, or how not to act, rooted in the possibilities (again, not the necessity) of human agency.

One of the main confusions concerning the relation between facts and opinion resides in this subtle line separating the pre-political and the political aspects of facts. Since "debate constitutes the very essence of political life" (idem, p. 237), the constitutional right to free-opinion can be invoked by someone who - intentionally or not - falsifies facts. The liar tries to pass a lie as an opinion. Whenever someone denounces his inaccuracy, he frames his falsification as only his opinion, which per force turns any factual truth over that matter into, simply, the opinion of others. In this regard, Arendt was clear: citizens are entitled to their own opinions, not their own facts. Citizens of democracies have the right to the most heterodox opinion, but no one has, or should have, the right to fabricate facts.

\section{UNEXPLORED PERPLEXITIES}

For Arendt, facts are paradoxical because of the very "price of freedom". They 
are supposed to be like the "sky...above us", permanent and seemingly independent from human decision. But they are not natural. They are not necessary: they spring from freedom, from human initiative, and refer to possible occurrences. Hence, they must be politically established, recorded and written down by a joint work of testimonies, researchers, writers, and independent reporters. Moreover, as human 90 events, in distinction from natural events and logical operations, facts are neither predictable nor self-evident. Being only evident, facts require a particular, detailed reconstitution of stories that have "no conclusive reason". Hence, by its internal structure, there is nothing compulsory in a fact. The opposite of a fact is not patently false or absurd. Indeed, there are infinite possible alternative stories to a factual truth which can plausibly be imagined.

It is possible to conceive a world where Germany did not invade Belgium. By also being rooted in contingency and freedom, political lies may achieve public success counting on legitimate political activities such as persuasion and imagination. So, for Arendt (idem, p. 253), "the possibilities for lying are boundless". The sky of facts may fall as an effect of perverted elements of freedom. Throughout the essay Truth and Politics, Arendt explored this tension between the stability of facts and its vulnerabilities. Peg Birmingham (2010, p. 75) rightly pointed to a paradox between "a stubborn thereness and an absolute contingency" of facts, between this quest for the endurance of facts and the threatening possibilities of fact denial.

There is, however, a perplexity which Arendt left unexamined in the article. In my view, it is an important source of political confusion: the relation between facts and their interpretative apprehension. Arendt indeed asked if facts exist "independent of opinion and interpretation". She emphasized that facts are "picked out of a chaos of sheer happenings" ultimately by choice, by particular criteria of selection and attention. But, trying to guarantee only an existence of "brutally elementary data" standing above particular ways of telling the story of these data, Arendt dismissed the point as providing "no argument" against facts themselves (ARENDT, 2006, p. 234). Every book or documentary telling the story of the German invasion into Belgium will be different, but the "elementary" aspects of the invasion are the same.

I do agree with Arendt's defense of the "brutally elementary" aspects of each fact and the plurality of opinions that can simultaneously emerge from it. But she could have gone deeply into asking if some forms of interpretation may destroy, instead of establishing, the meaning of a fact. To be sure, I do not hold that a fact must project only an exclusive meaning - it would contradict Arendt's perspectivism. Facts can be comprehended and signified in many ways. But Arendt herself was aware that certain forms of historical-analysis and fact-evaluation tend to neutralize the novelty and freshness of facts by putting them into schemes of justification, comparison, generalization. Throughout her whole work, Arendt complained against this mitigation and denial of facts by circular ideologies and obsessive patterns of reasoning, which dissolved particular stories within pre-made big narratives. In this context, one can ask: where does stand the line between fact-mitigation and fact-denial, between imaginative fact-interpretations and grotesque forms of fact-justification? Is evaluation of facts open to any sort of subjective reasoning or, in Arendt's terms, a proper "reconciliation with reality" demands not only recognition of factual verities, but also a politically shared comprehension of facts.

The point can be further discussed by resorting to the stories that motivated Arendt's own essay. Her defense of the primacy of facts was informed by the shocking novelty of totalitarian experiences, which, according to her, could not be understood on the basis of traditional examples. This conclusion was reinforced in her report about Adolf Eichmann. For Arendt, the "banal evil" of Eichmann's acts and his condition as a "desk murderer" were no speculative theses at all; they were descriptive formulations regarding his factual performance within the criminal structure of Nazism. Additionally, other polemical topic of her report - the passive behavior of Jewish leaders - pointed to no specific theory or interpretation. In her view, she only dealt with a disturbing fact 
that came up during the trial, and so "the controversy about the book is mostly about facts and not theses or opinions." (ARENDT, 2007, p. 485)

Here, Arendt seemed to underestimate the relation between fact, its interpretative apprehension and the meaning originated by this relation. Let us recall one of her own statements (2005, p. 61) on the issue of the Judenräte under Nazi occupation:

"To a Jew this role of the Jewish leaders in the destruction of their own people is undoubtedly the darkest chapter of the whole dark story".

To be sure, Arendt stated this as a conclusion from a factually based correlation which indicated that the organization and centralization provided by Jewish councils facilitated the deportation of Jews. In places with no Jewish institutional hierarchies, there was more "chaos" but also more chances of survival (idem, p. 60). But here she dealt with more than "bare facts": she combined personal emotions ("To a Jew") with a strong word composition (their role in the destruction of their own people...) and a metaphor (the darkest chapter in a dark story) that implies hidden links of explanation (Why is it the darkest chapter for Arendt? Probably because, "To a Jew", the degradation of Jews caused more sorrow than that of other groups). Arendt combined "elementary facts" (such as the passive behavior of Jewish leaders) with emotional claims, judgments and correlational speculations on the "might have been otherwise". Historians even denounced Arendt's "haphazard treatment of historical data" (LIPSTADT, 2011, p. 185).

In other words: interpretation and facts penetrate each other creating a symbiosis that establishes meaning. Arendt herself, in her early writings, recalled the moment when Jews lost their faith in the idea of a sacred beginning and a messianic end of history, being left with no "guide through the wilderness of bare facts". According to her (2007, p. 378), "when man is robbed of all means of interpreting events he is left with no sense whatsoever of reality". In this line, one may ask: are collective, shared interpretations required to establish these guides "through the wilderness of bare facts"? Conversely, would not a politically shared consciousness over facts imply a monopoly of history by official or dominant narratives, which would undermine interpretative plurality and openness?

From a commonplace perspective, this issue can also be exemplified with the attitude of holocaust deniers. Indeed, a more nuanced form of denial was called revisionism. Self-framed revisionists implied that they did not want to deny facts but only to revise the way these facts were told. Instead of simply denying the existence of extermination camps and gas chambers, they engaged in more subtle forms of mitigation or justification of what had happened - by claiming, for instance, that the number of victims was not so high, that victims were only civil casualties, that German civilians were equally slaughtered, that Jews explore holocaust narratives for their own interests etc. In this, revisionism relies on methods similar to those employed by the Nazis themselves after Auschwitz - when they framed their acts as a mere defense against the "criminal nature" of Jews (HILBERG, 1961, p. 656) - and also after Auschwitz, during trials - when most Nazis did not deny their acts, but did seek one or another form of justification.

What is at stake in such cases is not the factual matter itself, but how one apprehends it in a context of interpretation. Interpretation, with all the inherent risks of mitigation, justification, and normalization of the most shocking facts, may be at the core of political discord and crisis. Let us recall the way that the $9 / 11$ attacks were received throughout the world: while some mourned the victims holding, proudly, the U.S. flag, others burnt the U.S. flag celebrating the attackers. The fact itself was left intact (in times of live television, it could not be denied anyway). In Brazil, the last period of military dictatorship (1964-1985) is generally accepted in factual terms. Everyone knows that there was a coup, a government by force, relying on censorship and torture, with no political opposition. But there is no consensus regarding interpretations and evaluations of the period: some see in it incontestable violations of human rights; others praise the Army for having defeated insurgents who wanted to 
establish a communist autocracy; still others justify the political oppression for having produced the benefits of social order and personal safety.

For Arendt, however, it was preferable to leave democratic interpretation open to the most bizarre opinions than controlling public deliberation. Paraphrasing her, there can be no line between a set of "correct opinions" and "dangerous thoughts". Moreover, though she did not explore further the problem of interpretation in Truth and Politics, she did insist that comprehension is not justification, neither reduction to monistic lines of explanation. Indeed, she identified (2006, p. 237) objectivity with "considering a given issue from different viewpoints" and "being and thinking in my own identity where actually I am not". Interpretation of facts is an exercise in openness, in trying to enlarge one's mind and one's vision to cover different perspectives on the same matter. Historical and political facts can only be "revised", and brought into new spaces of clarity, as long as they are appreciated by impartial judges and citizens - and impartiality, in Arendt's terms, does not mean a detached neutrality, but a capacity to imagine and represent different standpoints.

\section{THE EMERGENCE OF MODERN LYING}

Concerning the reality of facts, there was a much more problematic onslaught than the distortion of facts by questionable lines of interpretation. Arendt referred to a specific form of modern lying. Conceptually, it related to the modern belief "that truth is neither given to nor disclosed to but produced by the human mind" (emphasis added; ARENDT, 2006, p. 226). The critique of this modern move - from reality inward to the mind - is central in Arendt's work, and crucial to understand her take on truth and politics. She defined (1998, p. 284) as typically modern the placement of the subjective mind as the "Archimedean point". According to this position, reality would not be given to the mind, but created (and so open to dissolution, deconstruction, recreation) by the mind.

This mindset could be politically verified in the way that even democratic governments, in the $20^{\text {th }}$ century, built some of their policies upon fabricated images or gross lies. Charles de Gaulle governed supported by the myth that France was a victor in World War II, while Konrad Adenauer repeated that Nazism reached only a small portion of Germans. They led their countries with "such evident non-facts" (ARENDT, 2006, p. 248). In the US, the Vietnam War was sustained not in order to pursue a specific economic or military goal but for the sake of promoting an "image" of the country as the most powerful in the world (ARENDT, 1972, p. 45). Bombs were dropped to "prove" the claims of propaganda. This trend to replace reality with images, beliefs, ideologies, emotions, thus turning reality simply into what people believe in, became a major source of what Arendt called world-alienation.

But no experience promoted a stronger attack on factual truths as totalitarianism. Arendt referred to "organized lying" as one of the main elements of totalitarian movements. It built a whole order upon the dissolution of external, objective facts, which were replaced by the fiction of totalitarian ideologies. The "facts" that Trotsky did not exist, that the subway of Moscow was the best in the world, that Jews controlled New York, London, Moscow, and were born with a "criminal nature", stood beyond doubt, for reality was then determined by ideology. The evidences concerning the existence of a man called Trotsky, of better subway-lines than Moscow's, of peaceful, powerless, innocent Jews were invalidated by the "ideas" of ideologies that supposedly presented a truer, more fundamental reality.

But there was more: the attack on propositions turned into an attack on concrete reality itself. The "making of another reality" (ARENDT, 2006, p. 249) surpassed the realm of sentences, slogans and linguistic claims. Totalitarianism aimed at destroying and reconstructing a world in accordance with its ideological tenets. E. Fackenheim called (1973, p. 193) it the "translation of fantasy into reality". If Stalin determined that 
Trotsky never existed, this meant not only that he should be erased from pictures and books, but that he also must die. Totalitarians sought to destroy what contradicted their ideology, so to build a world in accordance with their "beliefs" - which, in their minds, were not simple beliefs but descriptions of reality itself. So totalitarian statements anticipated destructive acts: in order to prove that Moscow trains were superior, the only thing needed was to destroy the subways of Paris, London etc.; if Jews were a decaying race, nothing more natural for them than to perish in camps that only accelerated their decadence.

Modern lying brings within it a violent drive for negation and destruction. This is different from classic lying. Traditional liars - diplomats, politicians, demagogues aimed at particular lies and therefore at limited portions of reality. Moreover, they knew internally what was true, being just satisfied with concealing that particular truth. So they never attacked the status of truth and reality as such. They deceived others, but not themselves. They only sought to create "a hole in the fabric of factuality", but kept intact the very notions of factuality and external objectivity. Totalitarianism, on the other hand, aimed at fabricating a new reality according to the blueprint of its allencompassing ideology.

The difference between traditional lie and its modern counterpart is, in short, that "between hiding and destroying" (ARENDT, 2006, p. 248). This generalization of lying and destruction led, according to Arendt (2006, p. 253), to contexts of "selfdeception", when people lost their "bearings in the real world". In these contexts, there is no appeal to criteria of true and false because men and women lose their social and individual resources to describe and verify what happens in the external world. Robert J. Lifton, after years studying former prisoners of "thought reform" (or "brainwashing") in China, has pointed to a common feature among them: the loss of a sense of reality, of a capacity to ascribe veracity to experienced situations or even emotions. By being conditioned to adjust their thoughts and feelings to official doctrines, these "thought prisoners" were submerged in a state of confusion and deception, becoming unable to differentiate what was real and what was illusory (LIFTON, 1989, p. 45).

\section{REALITY, OR ESCAPING THE PRISON OF HUMAN MIND}

Today we are facing a renewed onslaught on factual truths which should be considered in the context of what Hannah Arendt called modern lying. "Madison Avenue Methods" (ARENDT, 2006, p. 250) and proto-totalitarian expedients explore the potential of lying both in authoritarian and democratic countries. There is a combination of forms and levels of lying: mass propaganda favors images and representations over factual information; modern demagogues nurture an increasing sense of confusion by attacking traditional truthtellers and reclaiming truth as a function of government; social media, with no inner mechanisms to establish the truthfulness of their shared content, promote equally truths and lies (according to the MIT research, lies more than truths); ideological "echo chambers", fed according to the "confirmation bias" (the propensity to seek data that confirms one's beliefs), reinforce the sense that truth is always a particular truth generated by a specific group-interest.

As we have seen, Hannah Arendt tried to move beyond this "clash" between truth and politics, by liberating politics from the absolute "One Truth" of old metaphysics, but also by stabilizing political communities around the factual truths of acted deeds and spoken words in "commonly recognized realities". By doing so, she tried to reestablish, using traditional terms, a certain objectivity which would not cancel subjectivity. She even referred (2006, p. 258) to this "so called objectivity" (emphasis added), implying a specific form of stability which refused both absolute objectivity and absolute subjectivity. She refused, in short, one-sidedness. As we have seen, reality's objectivity is constituted by "different viewpoints", and not by exclusive apprehension. 
Arendt also framed reality as a "conditioning force" standing outside the subjective mind. She recalled (1998, p. 137) the German term for object - Gegenstand - as something which stands against someone. She also stated (2006, p. 252) that reality may be "shocking", that whenever someone tries to live as if reality could be replaced by an image, a fabrication or a subjective belief, "reality takes it revenges". To avoid a purely mystical connotation, one must remember that Arendt addressed these issues from a political perspective, that is, from the perspective of human plurality. Factual reality is neither given by nature (a cyclical, pre-human force) nor by God (an absolute, abstract, trans-human force). It is rather enacted and established out of the contingent acts of finite human beings, which amounts to stories and experiences recorded, in common language, as factual truths.

If, for instance, it may be said that the existence of the Sun is purely objective, and the existence of God is purely subjective, the existence of factual reality combines objective experiences which are informed by intersubjective principles and ideas, and by subjective apprehensions and evaluations. In this sense, factual reality is given by the unpredictable, uncontrollable interactions of plural men, whose experiences result both from conscious intentions and unexpected accidents. Men experience (act upon) and establish (work upon) reality, but no one fabricates reality according to his or her own will. The claim that reality is merely fabricated presupposes total control, absolute intention and a simple "author" or artifice. Historical-political actions are not simply made by someone (like God, Man, the Nation, the Leader etc.), but interacted by men and women who are vulnerable to nemesis, the force of contingency and tragedy.

Hence, if it is right to say that there is no factual truth outside the realm of human politics (that is, outside the realm of men who perform stories, tell these stories, memorize these stories etc.), it is wrong to say that truth is only within the human mind. Factual truths describe what happened in external reality. They are not arbitrary fictions imposed by dominant subjectivities. In this line, Arendt returned, to some extent, to the notion of truth as the adequacy of the intellect to things. But the "things" signified by factual statements are experiences which are performed by human interactions, depending on human witnesses and records, to be finally incorporated by a human world of memory. There, they become a sort of stable "sky" and "ground", which can nevertheless be seen by different views and walked through different paths, whenever these facts are put in a "context of interpretation".

\section{CONCLUSION: CAN THERE BE ALTERNATIVE-FACTS?}

After all, following Hannah Arendt, the question Can there be alternative-facts? can be answered in a contingent way: it depends. Politics is the realm of possibilities, including the possibility of lying. Yes, "alternative-facts" (that is to say, lies) can assume a certain reality, for, as we have seen, lying explores political capacities (persuasion, imagination) and public institutions (the constitutional right of free communication) to create "boundless" possibilities. Ideologies and image-making create a "web of deceptions", based on lies but with real consequences. In democratic countries, politicians are routinely elected relying more in their projected images than in their factual records. If an electoral majority believes that Trump's statements are truer than those of any other source, it means that lying can be established as a working reality. As both Arendt and the MIT research suggested, lying tends to satisfy cognitive appetites of the human mind, which is open to accept persuasive or convenient lies. In this regard, "there is no remedy" (ARENDT, 2006, p. 253) against public lying.

But, more fundamentally, Arendt indicated that the ultimate answer is perhaps no, there can be no alternative facts. She provided several arguments for that. "Organized lying" involves a virtually impossible task, that of rewriting history coherently. Erasing Trotsky from history means not only erasing him from pictures and birth certificates, but rewriting all events and circumstances in which he was involved - 
so the stories of the Red Army, the Civil War, the Party Congresses and so on should be described anew (ARENDT, 2006, p. 252). Hence, the liar would start an uncontrollable process in changing the past. Even though he wants to control history, he would begin to act over the past and the present, initiating another unpredictable series of consequences. In this line, Arendt stated (2006, p. 251) that "images have a relatively short life expectancy", since not even strong power-formations are able to impose their images for a long period.

Arendt pointed to this "stubbornness of facts", which resist and stand as a ground of common, memorable experiences beyond partisan inclinations. This "force" of reality relates to the human "compulsion" of telling factual truths (ARENDT, 2006, p. 235) and establishing stable references for orientation and communication. Factual truths are required for a "perseverance in existence" (ibid, p. 225). A "post-truth" reality would mean no reality at all, and "alternative-facts" would imply that there are no facts to start with. If we dismiss factual truths, there are neither reality nor politics, since, apart from offering a sort of collective stabilization, facts condition discussion, interpretation, decision-making, problem-solving. In Arendt's vocabulary, there can be no action and no change without a stable past and an identifiable present reality. The future is open to change, not the past.

At the core of the issue lies Arendt's meaning of politics - and the "actual content of political life" (2006, p. 258). For her (idem, ibid.), politics did not mean, ultimately, "this lowest level of human affairs", this linguistic and mental clash between groups, this "battlefield of partial, conflicting interests where nothing counted but pleasure and profit, partisanship, and the lust for domination". Echo chambers and confirmation bias are phenomena of world-alienation. They can be real, but they undermine the establishment of a common reality. Factual truths can only make sense if one appreciates the "actual content" of politics, of "being in company with our peers" (idem, ibid.). To be sure, this implied no utopian, harmonious formula for Arendt. It only meant the acceptance of external reality as the result of web of interactions, whose objectivity stands beyond "the distorting forces of power and interest" (idem, p. 247).

That is why the "refuges of truth" (idem, p. 256) - universities, the judiciary, the press, independent writers etc. - can be said to be political, but only in this second sense. Those working in these refuges should refrain from being "political" in the first sense, partisans, for

"...the teller of factual truth, when he enters the political realm and identifies himself with some partial interest and power formation, compromises on the only quality that could have made his truth appear plausible, namely, his personal truthfulness, guaranteed by impartiality, integrity, independence." (idem, p. 245-246)

Storytellers are not interested in justifying certain facts in accordance to obsessive-particular narratives. In finding out, guarding, and suggesting interpretations of factual truths, these men and women amplify our sense of reality, which Arendt characterized (1998, p. 57) as "sameness in utter diversity". They enlarge our repertoire of stories, add new examples of human performances, and offer meaning to the incessant movement of public affairs. By teaching "acceptance of things as they are" (ARENDT, 2006, p. 258), storytellers portrait men and women as they disclose themselves, as they are in their acts, words and stories - and not as some groupformation or some dictator want them to be. They establish the truths of human stories, with which men and women can augment their understanding and exercise their judgments over concrete examples of humanity. It is only seeing and hearing the adventures and the sorrows of present or past men, coward or brave, moved by vice or inspired by virtue, magnanimous or megalomaniac, republican or authoritarian, that one can grasp what men and women are, or were, in their public lives.

This is far from being a settled question. As I stated before, the question is contingent, for it requires persuasion, action and work for the sake of recognizing, establishing, and making sense of factual truths. Agents favoring fictions such as "alternative-facts" and "post-truth realities" are everywhere trying to convince others 
that reality is created through a continuous game of power, leading only to fragmentation and public-alienation, a game in which the stronger takes power by the force of its partial narrative. It is quite possible that a large part of humanity will still live in self-deception, supported by convenient images, self-fabricated myths or encapsulated interests. Arendt's contextual, historical argument relied on such examples, but it simultaneously pointed to how the expedients of lying and deception are related to the erosion of political institutions and communitarian relations. Saying no, there can be no alternative-facts, and acting and working on behalf of the preservation of factual truths, are political tasks of first importance. Facts may be "stubborn", but they only exist with political responsibility towards them.

\section{REFERENCES}

ARENDT, Hannah. Between Past and Future: eight exercises in political thought. New York: Penguin Books, 2006. Eichmann and the Holocaust. London: Penguin, 2005 . The Human Condition. Chicago: The University of Chicago Press, 1998.

.The Jewish Writings. Edited by Jerome Kohn and Ron H. Feldman. New York: Schocken Books, 2007. .The Origins of Totalitarianism. London: Penguin Classics, 2017.

.Washington's 'Problem-Solvers' - Where They Went Wrong. New York Times, New York, 5 April. 1972. p. 45

BIRMINGHAM, Peg. A Lying World Order: political deception and the threat of totalitarianism. In: BERKOWITZ, Roger; KATZ, Jeffrey; KEENAN, Thomas (Org.). Thinking in Dark Times: Hannah Arendt on ethics and politics. New York: Fordham University Press, 2010, p. 73-77.

CARR, Edward H. What is History? Penguin: Middlesex, 1986.

FACKENHEIM, Emil L. Encounters Between Judaism and Modern Philosophy: a preface to future Jewish thought. New York: Basic Books, 1973.

HILBERG, Raul. The Destruction of the European Jews. New York: Harper \& Row, 1961. KEAN, John. Post-truth politics and why the antidote isn't simply fact-checking and truth. In: The Conversation, mar. 2018. Disponível em: http://theconversation.com/posttruth-politics- and-why-the-antidote-isnt-simply-fact-checking-and-truth-87364

KOHN, Jerome. Hannah Arendt's Jewish Experience: thinking, acting, judging. In: BERKOWITZ, Roger; KATZ, Jeffrey; KEENAN, Thomas (Org.). Thinking in Dark Times: Hannah Arendt on ethics and politics. New York: Fordham University Press, 2010, p. 179-194 LIFTON, Robert J. Thought Reform and the Psychology of Totalism: a study of 'brainwashing' in China. Chapel Hill: The University of North Carolina Press, 1989.

LIPSTADT, Deborah E. The Eichmann Trial. New York: Schocken Books, 2011. VOSOUGHI, Soroush; ROY, Deb; ARAL, Sinan. The spread of true and false news online. In: MIT Initiative on The Digital Economy, mar. 2018. Disponível em: http://ide.mit.edu/sites/default/files/publications/2017\%20IDE\%20Research\%20Brief\%2 0Fal se\%20News.pdf

\section{Notas}

1 Arendt and the MIT research team, however, offered opposite reasons for the public success of lies: while Arendt stressed that, compared to shocking facts, lies may "sound more logical" and plausible (Arendt, 2006, p. 247), the MIT team concluded that "false news [are] perceived as more novel than true news", so that liars explore unexpectedness as an element of attraction. The distinction does not undermine the claims of this article. 